\title{
Education and Training Centre At Science And Techno Park USU Kwala Bekala
}

\author{
A. D. Nasution* and S. N. Puteri \\ Architecture Department, Faculty of Engineering, Universitas Sumatera Utara, Medan, Indonesia \\ *email: a.delianur@usu.ac.id
}

Submitted: 15 January 2020 Revision: 24 January 2020 Online: 30 January 2020

\begin{abstract}
Education and Training Center is a place where all activities to give, obtain, improve, and develop work competencies, productivity, discipline, attitude, and work ethic at a certain level of skills and expertise by the qualifications of a job or a job. (UU RI, 2003). The method is to create an Education and Training Centre. Education and Training center society as informal education in improving competence or quality for individuals. The Education and Training center is one of the most important buildings in the USU Kwala Bekala Campus. The USU Kwala Bekala campus divided into several zones. The entrance zone is the main gate that describes the initial image of the USU Kwala Bekala campus. This zone designed with the concept of Science \& Technology Park. Because the site location located in the entrance zone, the building design as "Building as A Gate," where the building is designed to create the impression of the entrance on the site. Then, at the main entry point, it was strengthened by the existence of a vista that led to USU's reservoirs and guesthouse. The building is also designed to integrate with the surrounding buildings. The design in STP built with the concept of green architecture. With the green architecture concept, the building will be more environmentally friendly for public health. Some things that considered in green architecture are the concept of energy saving. This project will explain how to design an education and training center by applying the green architecture theme to the STP area in USU Kwala Bekala
\end{abstract}

Keyword: education, science, techno park, training

\section{INTRODUCTION}

The design of the Education and Training Center at the Science \& Techno Park Area at USU in Kwala Bekala designed as a platform for training activities and academic research to improve the skills, knowledge, experiences related to acquiring skills or knowledge that can provide benefits to society and the environment. Then it was designed at Science \& Techno Park area of USU Kwala Bekala that combines industry, college, entrepreneurship research, and training center to create an integrated Area to enable the flow of information and technology more efficiently and quickly. Science Techno Park or Science Park is an area that combines industry, universities, research and training centers, entrepreneurship, banking, central and local government in a location that enables the flow of information and technology more efficiently and quickly. The Green Architecture theme applied to the building design in the USU Kwala Bekala area. Because by the existing masterplan concept of buildings in the region will be planned for the future. Application of green architecture concept on STP USU Kwala Bekala area based on UI GreenMetric Guideline 2017 Indonesia.

Science Techno Park or Science park is an integrated region that combines industry, universities, research and training centers, entrepreneurship, banking, national and local government in a location that enables the flow of information and technology more efficiently and quickly [1]. The development of Science \& Techno Park (STP) is one of the sixth grain programs of Nawacita Government of President Joko Widodo: some building of science \& techno park in areas, polytechnics and SMKs with the latest infrastructure and facilities with technology. The objective of this program is to increase community productivity and industrial competitiveness in global markets. According to KBBI (2017), Education is the process of 
changing the attitude and behavior of a person or group of people to mature human beings through the efforts of teaching and training; processes, ways, actions educate [2]. Definition of job training according to Government Regulation of the Republic of Indonesia number 31 on National Work Training System is job training is the whole activity to give, gain, improve, and develop work competence, productivity, discipline, attitude, and work ethic and skill level according to ladder and qualification Occupation or occupation [3]. The Green Architecture leads to the structure and usage of environmentally responsible and resource-efficient processes throughout the life cycle of the building, from site selection to design, construction, operation, maintenance, renovation and demolition [4]. The green architecture design approach refers to The UI Green Metric. UI Green Metric World Ranking is an initiative from Universitas Indonesia which launched in 2010 on the green university rankings.

\section{METHODS}

Campus USU Kwala Bekala is a step to the needs of the land along with the increasing number of USU students. The purpose of the development of USU campus in Kwala Bekala to produce campus planning that can support activities: Education \& Teaching, Research, and Community Service. Supporting Zone of the area of Science Techno Park USU Kwala Bekala. This area focused on academic, research, and economic. Located precisely in the entrance zone, supporting area, and reservoir with a total land area of $64.76 \mathrm{Ha}$.

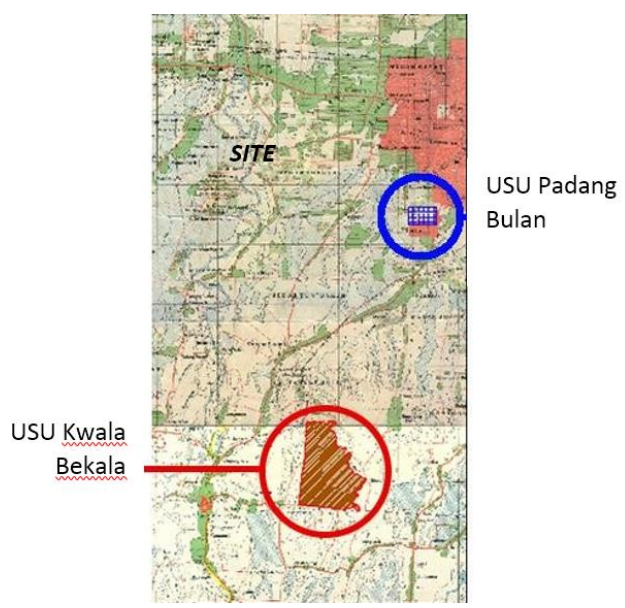

Figure 1. Site Campus USU Kwala Bekala (Source: RTBL book USU Kwala Bekala, 2016)
Land located in the entrance zone of USU Kwala Bekala with area of 2.7 ha. The Training and Education Center is one of the facilities of the main entrance area. Currently, USU has had several research institutes to accommodate research activities at the University of North Sumatra. In its development, it expected that USU academic community could continuously improve the research activity and produce new and applicative scientific method and concept. The results of the research are applied by one of the USU mission is "to increase the role of USU in fostering rural communities, through the improvement of science and technology and practice by available human resources."

The design of The Education and Training Center designed with the Green Architecture theme approach. The guidelines of green architecture based review literature such as UI Green Metric Guidelines 2017, National Standard Body of Indonesia, Metric's book, and others (Figure 1).

\section{RESULTS AND DISCUSSION}

\section{Supporting Zones STP and Zone Entrance Area USU Kwala Bekala}

Supporting Zone of the area of Science Techno Park USU Kwala Bekala. This area focused on academic, research, and economic. Located precisely in the entrance zone, the support area, and the reservoir (Figure 2).

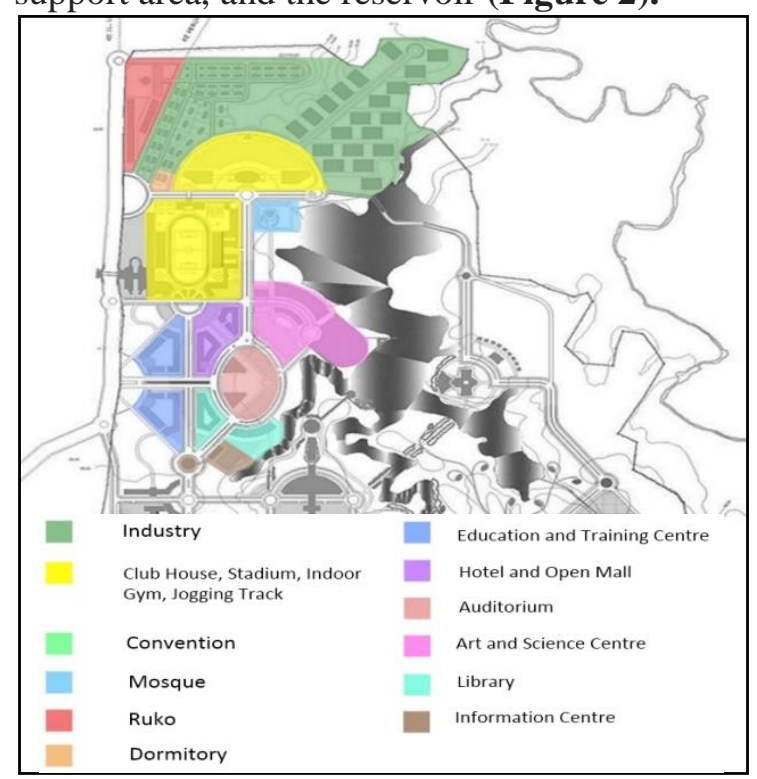

Figure 2. Masterplan of Micro Area (STP) USU Kwala Bekala

(Source: Masterplan USU Kwala Bekala, 2016) 


\section{The Green Architecture Theme Approach}

Building on Campus USU Kwala Bekala applies tropical architecture concept in the tropics. Consideration of energy saving and response to the climate and environmental context form the basis of the implementation of this concept. The theme described in the following explanation.

Lighting that comes from the sun that comes from the morning before noon until late afternoon. The advantages of this lighting are cost-effective because it does not depend on electrical energy. So it can save electricity usage (Figure 3).

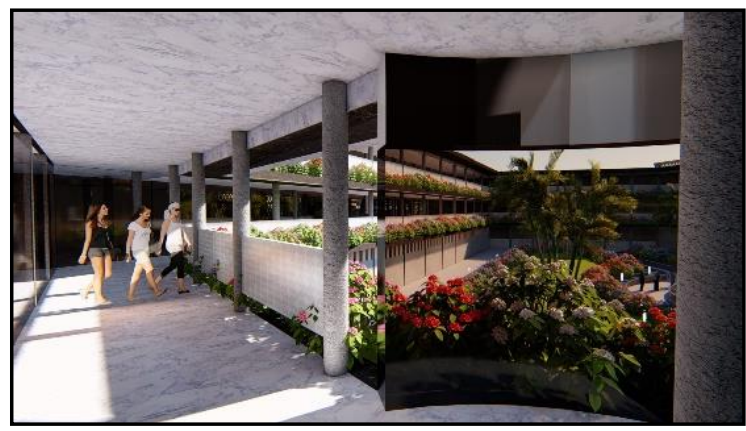

Figure 3. Natural lighting for hallway

Circulation building using a single loaded system to utilize light. Building users can access the room easily because of the circulation that surrounds every building's skin (Figure 4).

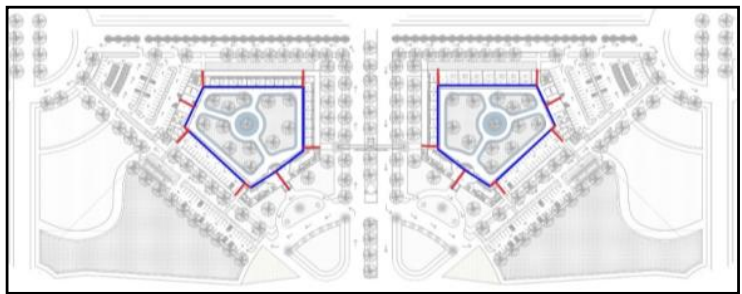

Figure 4. groundplan building circulation

The concept applied to the second floor. And then the room formed at the core of the building can make the user focus toward the middle of the building or inner court (Figure 5).

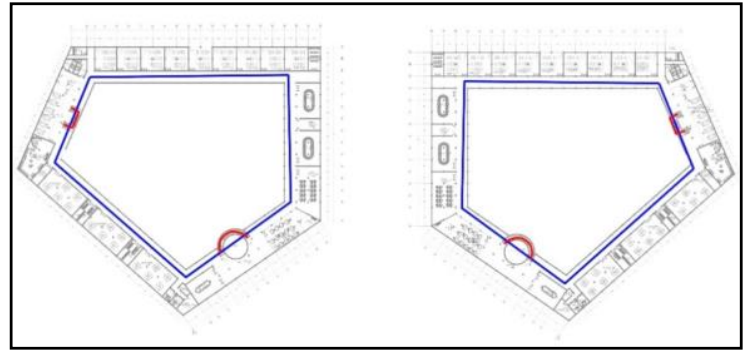

Figure 5. second and third-floor building circulation

The concept of natural air circulation made with cross-ventilation system. The process of air exchange that takes place inside the building through the help of open elements. Cross ventilation allowed air to flow freely over the site and into the plaza. Thus, air change can keep moving to create fresh air. (Figure 6).

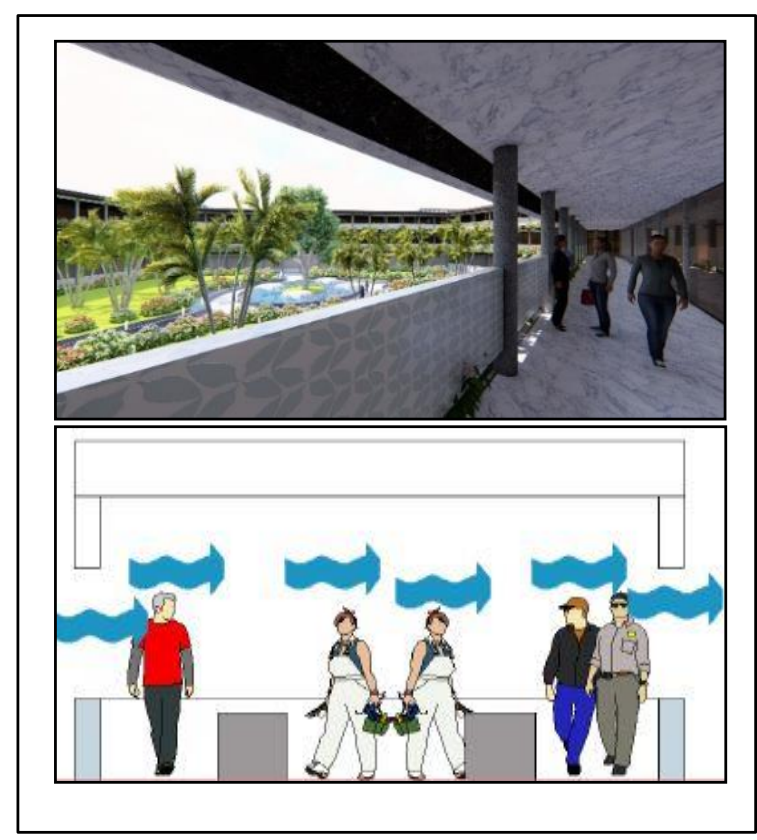

Figure 6. Natural air circulation

Garbage collection from the building done every day after work hours and then trolley garbage is parked temporarily along the road around the building. For outdoor provided garbage cans in certain places beside the road so it can reached by garbage collecting truck (Figure 7). 


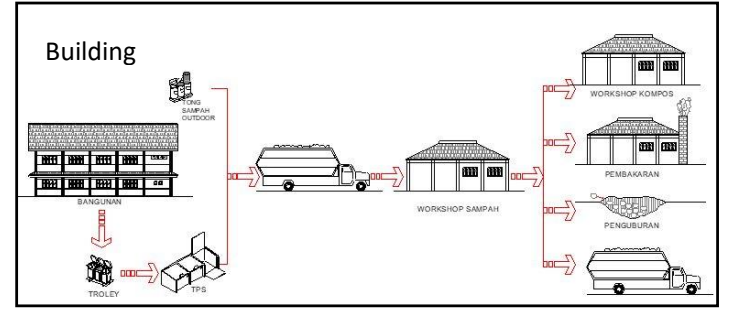

Figure 7. Waste Management

(Source: Masterplan USU Kwala Bekala, 2016)

Shading is a concept for filtering sunlight, as well as the aesthetics of buildings. In the design, shading will be made with the vertical and horizontal arrangement, to filter incoming sunlight, as well as the shadows on the interior of the building. Metal façade for flexible air movement and add aesthetic of the building. (Figure 8).

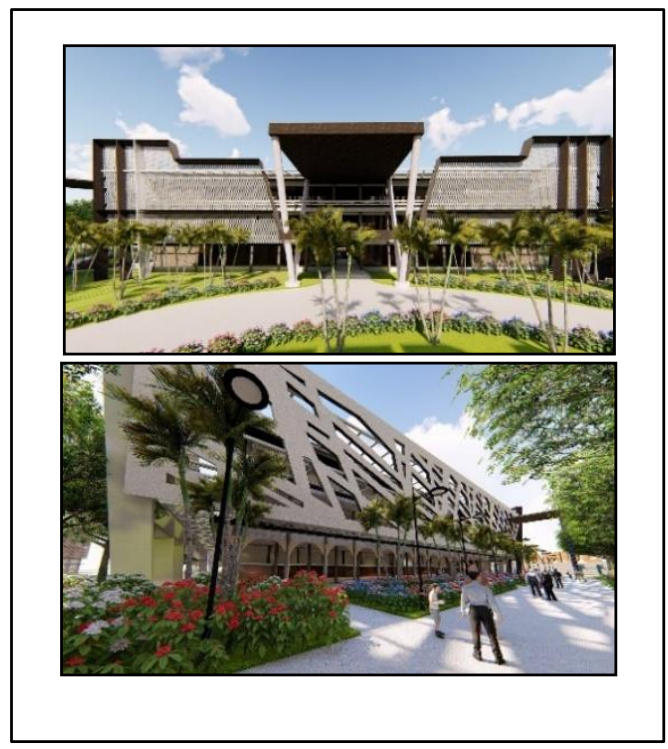

Figure 8. Secondary façade and shading

The unifying platform of several clusters and open spaces between buildings in the campus training campus USU Kwala Bekala is laid out on a familiar scale for users with pavement patterns, vegetation and subdivision arrangements filled with public function buildings (mosque, canteen) or open-space furniture (gazebos, shelter, outdoor seating) (Figure 9).

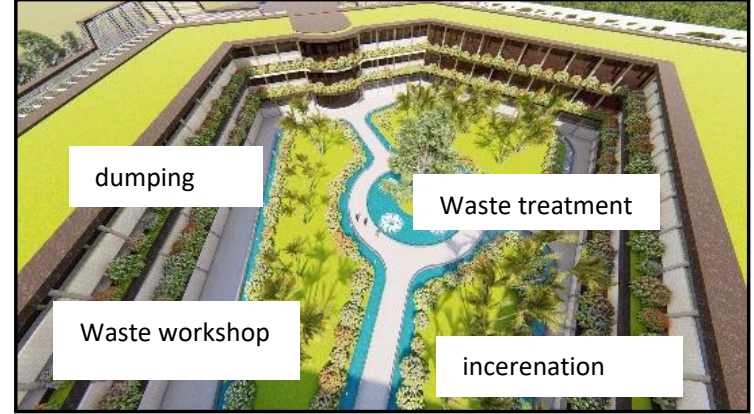

Figure 9. Plaza cluster

\section{Outdoor and Inside Spatial Planning}

Around the entrance, the masses are arranged lengthwise on both sides along the boulevard with the orientation to it. This concept designed to define a straight road corridor leading to the vista end of an open plaza on the edge of a reservoir and a landmark building across it. (Figure 10).

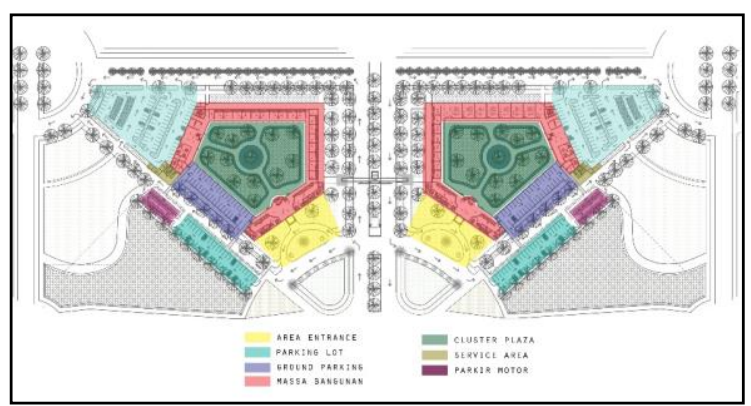

Figure 10. Zoning Outdoor

In the building, there are two entrances. The first through the front door of the main road, and the second from the parking. The side of the building facing the way to the campus made for a business start-up. To be seen by pedestrians. Floor 1 also used for training center activities (Figure 11).

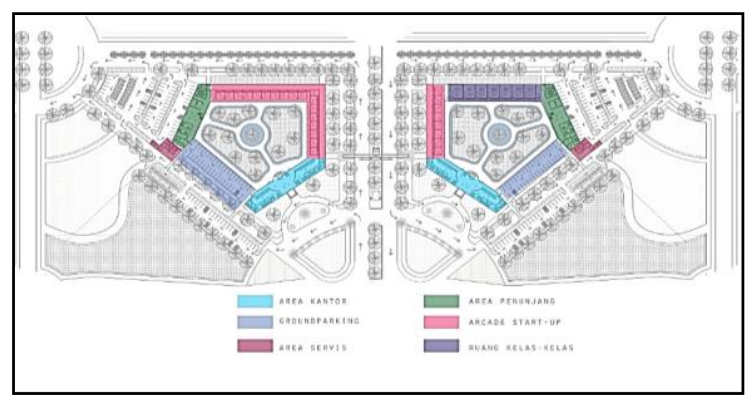

Figure 11. Zoning groundfloor 
Then, in the center of the building, there is a plaza for building orientation. The unifying platform of multiple clusters and open spaces between them laid out on a familiar scale for users with pavement patterns, vegetation and subdivision arrangements filled with public function buildings (mosque, canteen) or gazebo, shelter, outdoor seating (Figure 12).

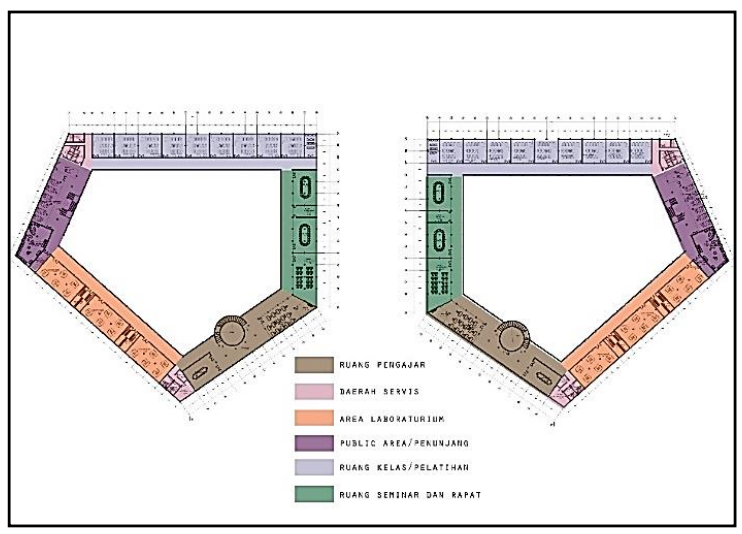

Figure 12. Zoning second and third floor

\section{Mass and Appearance}

Mass designed with a plaza in the middle of the building as the orientation. The Plaza is also a unifying cluster of buildings. Thus, buildings can get sunlight from the plaza and from outside the site. With the formation of two equal masses along the main entrance, creating the impression of a steering gate as the entrance gate. Also has a formal nature as training and office buildings. It strengthens the concept of Building as a Gate (Figure 13).

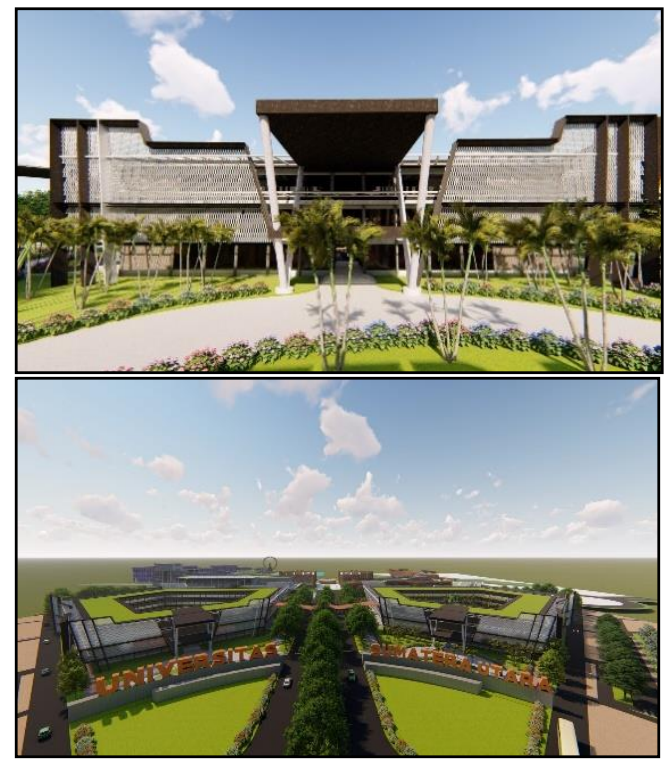

Figure 13. Mass concept

\section{Structure and Construction System}

The structure used in this building mass consists of two types. There are the foundation and building structures. The foundation structure uses a pile foundation and reinforced with a structural system of columns and beams. In this building, using a $30 / 25$ size beam while diameter column is $40 \mathrm{~cm}$.

\section{CONCLUSION}

The Education and Training Center at USU Kwala Bekala located at the entrance zone of the Academic Area is one of several supporting building functions in the Tech Park area of USU Kwala Bekala at gate area as "Building as a Gate." With the building area range approximately 19.884 $\mathrm{m}^{2}$, The Education and Training Center is expected to serve as a platform for training activities and academic research to enhance the skills, knowledge, experiences related to acquiring skills or knowledge that can benefit society and the environment.

The Green Architecture chosen as the theme of the move from supporting the mission vision of USU Kwala Bekala 
University to create an environmentally friendly campus environment. it suitable to the tropical climate in Pancur Batu. The applied Green Architecture Principles are expected to have a good impact on people, buildings, and the environment around them [5].

\section{ACKNOWLEDGMENTS}

This article is written by researchers who are partly by Universitas Sumatera Utara and was given out as a donation to the government to preserve and improve the value of design, local wisdom, arts and ethnic.

\section{REFERENCES}

[1] B. S. Silvestre, "Journal of Engineering and Technology Management," A typology of university research park strategies, 2018.

[2] B. P. d. P. Bahasa, "KBBI Daring," Kementerian Pendidikan dan Kebudayaan Republik Indonesia, 2016. [Online]. Available:

https://kbbi.kemdikbud.go.id/entri/pendidi kan. [Accessed 2018].

[3] H. Awaludin, "Permen Republik Indonesia Nomor 31 Tahun 2006," Sistem Pelatihan Kerja Nasional, 2006.

[4] K. Beattie, "Sustainable Architecture and Simulation Modelling," Dublin Institute of Technology , 2017. [Online]. Available: http://www.cebe.heacademy.ac.uk/learning /habitat/HABITAT4/beattie.html.

[Accessed 2018].

[5] Achmad Delianur, "Indonesia International Conference on Science Technology Park," The Development of Kwala Bekala Technobiz Park (KBTP) University of Sumatera Utara, vol. II, p. 146=152, 2017.

[6] R. W. Berman, Assesing Urban Design: Historical Ambience on The Waterfront, Lexingtoon Books, 2006.
[7] A. Amir and M. N. I. I. a. T. P. See, "Sustainable Tourist Environment: Perception of International Women Travelers on Safety and Security in Kuala Lumpur," Procedia-Social and Behavioral Science 168, pp. 123-133, 2015.

[8] D. S. a. L. Wilkes, "Understanding serviceoriented architecture," The Architecture Journal, vol. 1, no. 1, pp. 10-17, 2004. 